\title{
Methanol leaf extract of Actinodaphne sesquipedalis (Lauraceae) enhances gastric defense against ethanol-induced ulcer in rats
}

This article was published in the following Dove Press journal:

Drug Design, Development and Therapy

4 May 2017

Number of times this article has been viewed

\author{
Hanita Omar ${ }^{1,2}$ \\ Noraziah Nordin ${ }^{3}$ \\ Pouya Hassandarvish ${ }^{4}$ \\ Maryam Hajrezaie ${ }^{5}$ \\ Ainnul Hamidah Syahadah \\ Azizan' \\ Mehran Fadaeinasab ${ }^{6}$ \\ Nazia Abdul Majid ${ }^{7}$ \\ Mahmood Ameen Abdulla ${ }^{5}$ \\ Najihah Mohd Hashim ${ }^{3}$ \\ Hapipah Mohd Ali' \\ 'Department of Chemistry, Faculty \\ of Science, ${ }^{2}$ Centre for Foundation \\ Studies in Science, ${ }^{3}$ Department \\ of Pharmacy, ${ }^{4}$ Department of \\ Microbiology, ${ }^{5}$ Department of \\ Biomedical Sciences, Faculty of \\ Medicine, ${ }^{6}$ Center for Natural \\ Products and Drug Research \\ (CENAR), ${ }^{7}$ Institute of Biological \\ Sciences, Faculty of Science, \\ University of Malaya, Kuala \\ Lumpur, Malaysia
}

\begin{abstract}
Actinodaphne sesquipedalis Hook. F. Var. Glabra (Kochummen), also known as "Medang payung" by the Malay people, belongs to the Lauraceae family. In this study, methanol leaf extract of $A$. sesquipedalis was investigated for their acute toxicity and gastroprotective effects to reduce ulcers in rat stomachs induced by ethanol. The rats were assigned to one of five groups: normal group (group 1), ulcer group (group 2), control positive drug group (group 3) and two experimental groups treated with $150 \mathrm{mg} / \mathrm{kg}$ (group 4) and $300 \mathrm{mg} / \mathrm{kg}$ (group 5) of leaf extract. The rats were sacrificed an hour after pretreatment with extracts, and their stomach homogenates and tissues were collected for further evaluation. Macroscopic and histological analyses showed that gastric ulcers in rats pretreated with the extract were significantly reduced to an extent that it allowed leukocytes penetration of the gastric walls compared with the ulcer group. In addition, an ulcer inhibition rate of $>70 \%$ was detected in rats treated with both doses of $A$. sesquipedalis extract, showing a notable protection of gastric layer. Severe destruction of gastric mucosa was prevented with a high production of mucus and $\mathrm{pH}$ gastric contents in both omeprazole-treated and extract-treated groups. Meanwhile, an increase in glycoprotein uptake was observed in pretreated rats through accumulation of magenta color in Periodic Acid Schiff staining assay. Analysis of gastric homogenate from pretreated rats showed a reduction of malondialdehyde and elevation of nitric oxide, glutathione, prostaglandin E2, superoxide dismutase and protein concentration levels in comparison with group 2. Suppression of apoptosis in gastric tissues by upregulation of Hsp70 protein and downregulation of Bax protein was also observed in rats pretreated with extract. Consistent results of a reduction of gastric ulcer and the protection of gastric wall were obtained for rats pretreated with A. sesquipedalis extract, which showed its prominent gastroprotective potential in rats' stomach against ethanol-induced ulcer.
\end{abstract}

Keywords: Actinodaphne sesquipedalis, methanol extracts, gastric ulcer, ethanol, mechanism

\section{Introduction}

Gastric ulcer is considered the most prevalent gastrointestinal disorder in developed countries and has turned out to be a progressive worldwide health issue. Gastric ulcer is a condition where an erosion or a lesion in the gastric mucosa penetrates into the submucosa or deeper. ${ }^{1}$ One of the causes of this disorder is an imbalance between the protective factors (prostaglandin, bicarbonate, nitric oxide [NO] and growth factors) and destructive factors (infection by Helicobacter pylori, use of nonsteroidal antiinflammatory drugs and lifestyle),${ }^{1-3}$ resulting in disruption of the gastric mucosal defensive barrier leading to gastric ulcer. ${ }^{4}$ Gastroprotective agents prescribed for ulcer are generally nonspecific, by which the secretion of gastric acid is controlled
Correspondence: Hanita Omar

Centre for Foundation Studies in Science, University of Malaya, 50603 Kuala

Lumpur, Malaysia

Tel +60379675980

Fax +60 379576478

Email hanita74@um.edu.my
Drug Design, Development and Therapy 2017:| | |353-1365

(c) (1) (8) ๑ 2017 Omar et al. This work is published and licensed by Dove Medical Press Limited. The full terms of this license are avalable at https:/www.dovepress.com/terms.php cc) hereby accept the Terms. Non-commercial uses of the work are permitted without any further permission from Dove Medical Press Limited, provided the work is properly attributed. For permision for commercial use of this work, please see paragraphs 4.2 and 5 of our Terms (https://www.doveppess. com/terms.php). 
by antacids, $\mathrm{H}_{2}$ receptor blockers (ranitidine, famotidine) or proton pump blockers (omeprazole and lansoprazole), proton pump inhibitors or antihistamines. ${ }^{5}$ However, recently, these drugs are facing major problems due to their limited efficacy against gastric diseases and severe side effects.,

Due to these issues, continuous efforts to find suitable natural protective agents with gastroprotective properties need to be taken. One of the best strategies for the prevention and treatment of gastric ulcer which is currently gaining global attention is the use of medicinal plants. ${ }^{8}$ Medicinal plants and crude drug substances have been reported to have potential anti-gastric ulcer components that combat gastric ulcer as well as various diseases. ${ }^{9-11}$ In this study, we investigated the potential gastroprotective effect of methanol leaf extracts of Actinodaphne sesquipedalis, which belong to the family of Lauraceae, in rat models with ethanol-induced ulcer.

\section{Materials and methods}

\section{Plant materials}

The leaves of A. sesquipedalis Hook. F. var. Glabra (Kochummen) were collected from Reserved Forest Cameron Highland, Pahang, in 2011. The species was identified by the botanist of Malayan Herbarium, University of Malaya, with the voucher specimen number HIR 011.

\section{Extraction of plant}

The leaves of $A$. sesquipedalis were oven-dried at $40^{\circ} \mathrm{C}$ for a week and ground into a powder. The leaves (700 g) were extracted with methanol solvent for $72 \mathrm{~h}$ at room temperature (with occasional stirring). The mixture was filtered and concentrated using the rotary evaporator (Buchi, New Castle, DE, USA). The crude methanol leaf extract weighed $83.55 \mathrm{~g}$.

\section{Preliminary phytochemical investigations}

The preliminary phytochemical screening of the extract was carried out according to the standard procedures to determine the constituents present in the extract. ${ }^{12-14}$ The extract was screened for the presence of alkaloids, ${ }^{12}$ saponins, ${ }^{13}$ sterols and triterpenes, ${ }^{13}$ polyphenols, ${ }^{14}$ as well as tannins. ${ }^{12}$ Meanwhile, high-performance liquid chromatography (HPLC) was performed to determine the HPLC profiling of the extract using Agilent 1290 Infinity LC system.

\section{Animal study}

\section{Ethical issues}

The use of animals in this study was approved by the Ethics Committee for Animal Experimentation, Faculty of Medicine,
University of Malaya, Malaysia (ethical approval no PM/28/09/2006/1111/MAA (R)) (Supplementary materials). The animals were monitored and maintained according to the Guide for the Care and Use of Laboratory Animals prepared by the National Academy of Sciences and guidelines of the Organization for Economic Cooperation and Development (OECD).

\section{Omeprazole}

Omeprazole is a proton pump inhibitor commonly used for the prevention and the treatment of peptic ulcers. In this study, omeprazole was used as a positive control drug and was obtained from the Department of Pharmacy, University of Malaya Medical Centre (UMMC). The drug was dissolved in Tween $20(10 \%, \mathrm{v} / \mathrm{v})$ and used as the normal control. Meanwhile, the drug was administered orally to the rats $(5 \mathrm{~mL} / \mathrm{kg}$ ) at doses of $20 \mathrm{mg} / \mathrm{kg}$ of body weight according to the recommendation of researchers of a previous study. ${ }^{15}$

\section{Acute toxicity study}

Healthy ICR mice of 6-8 weeks of age and 25-35 g of weight were obtained from the Experimental Animal House, Faculty of Medicine, University of Malaya. The acute toxicity test was performed according to the guideline published by the OECD to determine a safer dose of $A$. sesquipedalis extracts. A total of 36 mice ( 18 males and 18 females) were divided equally into three groups and were labeled as Tween $20(10 \%, \mathrm{v} / \mathrm{v})$ vehicle control group, $1,000 \mathrm{mg} / \mathrm{kg}$ extract (low dose) group and 2,000 $\mathrm{mg} / \mathrm{kg}$ extract (high dose) group, respectively. Prior to dosing, the animals were fasted overnight except for access to water; however, water access was stopped for $2 \mathrm{~h}$ before and after the dosing, while food was suspended for $3 \mathrm{~h}$ after dosing. The mice received their respective dose of extracts $(5 \mathrm{~mL} / \mathrm{kg})$ at 1,000 and $2,000 \mathrm{mg} / \mathrm{kg}$ and were evaluated for 14 days for any toxicological symptoms. On day 15 , the animals were sacrificed under anesthesia (ketamine and xylazine). Blood sample was collected to analyze its biochemical properties using clinical laboratory diagnostics. Meanwhile, the liver and renal samples were processed for histological studies.

\section{Stimulation of acute gastric lesion}

The rats (175 and $210 \mathrm{~g}$ ) were obtained from the Experimental Animal House, Faculty of Medicine, University of Malaya, and randomly divided into five groups. Each group consisted of six rats which were kept individually in stainless steel cages with raised floors of wide-mesh wire bottoms to prevent coprophagia. They were maintained 
at a temperature of $25^{\circ} \mathrm{C}$ with a light-dark cycle ratio of $12 \mathrm{~h}: 12 \mathrm{~h}$. The animals were fasted for $24 \mathrm{~h}$ but were allowed free access to water till $2 \mathrm{~h}$ prior to the experiment. Group 1 was labeled as normal control and was gavage-pretreated with $10 \%$ Tween 20 ( $5 \mathrm{~mL} / \mathrm{kg}$ of body weight). Group 2 (ulcer control) was orally administered with vehicle $(10 \%$ Tween 20, v/v; $5 \mathrm{~mL} / \mathrm{kg}$ of body weight). Group 3 (positive control) received oral doses of $20 \mathrm{mg} / \mathrm{kg}$ omeprazole with vehicle ( $5 \mathrm{~mL} / \mathrm{kg}$ of body weight). Experimental groups (4 and 5) were pretreated $(5 \mathrm{~mL} / \mathrm{kg})$ with methanol leaf extract of two different doses (150 and $300 \mathrm{mg} / \mathrm{kg}$ ), respectively. Groups 2-5 received absolute ethanol after $60 \mathrm{~min}$ of pretreatment in order to induce gastric mucosal ulcer. ${ }^{16}$ All animals were sacrificed after an hour with an overdose of ketamine and xylazine anesthesia, followed by euthanization by cervical decapitation. Their stomachs were then instantly excised and immersed in 10\% buffered formalin solution prior to gastric lesions analysis. The blood samples were also collected from their jugular vein for further analysis.

\section{Measurement of acid content of gastric juice $(\mathrm{pH})$}

The gastric contents of each rat stomach were collected and transferred into a Falcon tube prior to centrifugation. The samples were centrifuged at $2,990 \times g$ for $10 \mathrm{~min}$. The hydrogen ion concentration of gastric content was measured using a digital $\mathrm{pH}$ meter.

\section{Measurement of gastric wall mucus}

The luminal surface of each stomach was removed and transferred into $10 \mathrm{~mL}$ of Alcian blue solution. The free dye was then removed by adding $10 \mathrm{~mL}$ of sucrose, while conjugated dye with the tissue was extracted using $0.5 \mathrm{M}$ magnesium chloride $(10 \mathrm{~mL})$. A total of $4 \mathrm{~mL}$ blue extract was mixed with $4 \mathrm{~mL}$ of diethyl ether and shaken vigorously for a few minutes. prior to measurement, the mixture was centrifuged at $2,990 \times \mathrm{g}$ for $10 \mathrm{~min}$. The quantity of Alcian blue was measured using a spectrophotometer at the absorbance of $580 \mathrm{~nm} .^{17}$

\section{Evaluation of gross gastric lesions}

Each stomach was carefully cut along a greater curvature and rinsed with normal saline to remove gastric contents. According to previous studies, the length $(\mathrm{mm})$ and the width $(\mathrm{mm})$ of each band of hemorrhagic lesions (ulcer area) were measured using planimeter $([10 \times 10 \mathrm{~mm}=$ ulcer area] under dissecting microscope $[\times 1.8]) .{ }^{10,15,18}$ The bands of hemorrhagic mucosal lesion which covered the length and width of each ulcer band were counted by calculating the number of small squares $(2 \times 2 \mathrm{~mm})$. The measure of all areas of lesions $\left(\mathrm{mm}^{2}\right)$ for each stomach was expressed as the ulcer area $\left(\mathrm{mm}^{2}\right) .{ }^{19}$

\section{Histological study of gastric wall}

The histological study was conducted using two different stains, hematoxylin and eosin (H\&E) and periodic Acid Schiff (PAS) ${ }^{20}$ Briefly, stomach tissues fixed in $10 \%$ buffered formalin were processed using paraffin tissue-processing machine (Leica, Wetzlar, Germany). The stomach tissues were embedded in paraffin wax and sectioned at $5 \mu \mathrm{m}$ thickness. Each specimen was then stained with H\&E stain and observed under a light microscope (Nikon, Tokyo, Japan). Meanwhile, PAS staining was done to evaluate the production of mucus in each stomach at the glandular part. The same procedure was carried out for PAS staining, in which a $5 \mu \mathrm{m}$ specimen of stomach tissue was stained with PAS prior to examination under microscope.

\section{Immunohistochemistry}

The immunohistochemical analysis of rat's stomach tissue was conducted using DakoCytomation staining protocol (Agilent Technologies, Santa Clara, CA, USA). ${ }^{21}$ In brief, the rat's stomach tissues were cut at $5 \mu \mathrm{m}$ thickness prior to deparaffinization and dehydration. Each section was then fixed on a glass slide treated with 3-aminopropyltrimethoxysilane and washed with a washing buffer. Each section of stomach was incubated for 15 min with a primary antibody (biotinylated), followed by staining with Hsp70 and Bax using streptavidin peroxidase detection reagents (Abcam, Cambridge, UK). A light microscope was used to observe the brown-stained regions which indicated positive findings.

\section{Biological activity of gastric tissue homogenate \\ Preparation of sample}

The preparation of gastric tissue samples was done using a homogenizer (Polytron, RZR 1; Heidolph, Schwabach, Germany) for the evaluation of its biological activity. A small fragment of each gastric tissue (about $200 \mathrm{mg}$ for each) was taken and homogenized $(10 \%, \mathrm{w} / \mathrm{v})$ in ice cold phosphatebuffered saline $(0.1 \mathrm{~mol} / \mathrm{L} ; \mathrm{pH} 7.4)$ consisting of mammalian protease inhibitor cocktail. ${ }^{22}$ The homogenates were then centrifuged at $18,000 \times g$ for $15 \mathrm{~min}$ at $4^{\circ} \mathrm{C}$. The pure supernatant was separated and further analyzed for the levels of superoxide dismutase (SOD), catalase, glutathione (GSH), malondialdehyde (MDA), prostaglandin E2 $\left(\mathrm{PGE}_{2}\right)$ and $\mathrm{NO}$. 


\section{Measurement of SOD activity}

The experiment was performed in a 96-well plate using Cayman's Superoxide Dismutase Assay Kit, based on the manufacturer's procedure. In brief, each well was added with diluted radical detector $(200 \mathrm{~mL})$, followed by $10 \mathrm{~mL}$ of standard and $10 \mathrm{~mL}$ of samples, according to the manufacturer's instruction. Prior to measurement, a total of $20 \mathrm{~mL}$ of diluted xanthine oxidase was added to each well and incubated for $20 \mathrm{~min}$ to initiate the reaction. The plate was then read using a microplate reader at a wavelength of $440-460 \mathrm{~nm}$.

\section{Measurement of NO}

Griess assay was carried out through the measurement of nitrite/nitrate concentration to measure the NO level. ${ }^{23}$ The supernatant was aliquoted carefully into several tubes and added with vanadium trichloride $(0.8 \%[\mathrm{w} / \mathrm{v}]$ in $1 \mathrm{M} \mathrm{HCl})$. The mixture was then added rapidly with Griess reagent (Sigma, St Louis, MO, USA), and absorbance was measured using a spectrophotometer at a wavelength of $540 \mathrm{~nm}$.

\section{Measurement of GSH levels}

Cayman's Glutathione Peroxidase Assay Kit was used to investigate the level of GSH in rat's stomach. The experiment was conducted in a 96-well plate. Each well was added with assay buffer and co-substrate mixture. The diluted glutathione peroxidase was then added into the positive wells and sample wells prior to measurement. Total GSH content was measured using a spectrophotometer at a wavelength of $340 \mathrm{~nm}$.

\section{Measurement of membrane lipids peroxidation activity}

Lipid peroxidation can be evaluated through the MDA level in the rat tissue using a Cayman's TBARS Assay Kit. Based on the manufacturer's instruction, a volume of $250 \mathrm{~mL}$ of prepared gastric supernatant was used in radioimmunoprecipitation assay buffer with a protease inhibitor. The experiment was performed in a $5 \mathrm{~mL}$ vial consisting of $100 \mathrm{~mL}$ of sample or positive control, $100 \mathrm{~mL}$ of sodium dodecyl sulfate (SDS) solution and $4 \mathrm{~mL}$ of the color reagent. The vial was then boiled for an hour, and the reaction was stopped by placing the vial in $-20^{\circ} \mathrm{C}$ for $10 \mathrm{~min}$. The mixture was centrifuged at $4^{\circ} \mathrm{C}$ at $1,600 \times \mathrm{g}$ for $10 \mathrm{~min}$. The absorbance of the supernatant was measured by a spectrophotometer at a wavelength of $532 \mathrm{~nm}$.

\section{Measurement of $\mathrm{PGE}_{2}$ level}

This assay was performed using a Cayman's $\mathrm{PGE}_{2}$ EIA Kit according to the manufacturer's protocol. In brief, the supernatant consisting of $\mathrm{PGE}_{2}$ was added into a 96-well plate, followed by four reagents: enzyme immunoassay (EIA) buffer, $\mathrm{PGE}_{2}$ EIA standard, $\mathrm{PGE}_{2}$ AChE tracer and $\mathrm{PGE}_{2}$ monoclonal antibody. All reagents were added successively into the 96-well plate. The absorbance of the plate was then measured at a wavelength of $420 \mathrm{~nm}$ using a microplate reader (UV-1201; Shimadzu Corp., Kyoto, Japan).

\section{Measurement of protein concentration}

Gastric homogenate of rat stomach was collected to determine the protein concentrations $(\mathrm{mg} / \mathrm{mL}$ tissue) of each stomach. Biuret reaction was used to calculate the protein concentration as described by Gornall et al. ${ }^{24}$ The concentration of protein was measured quantitatively by spectrometric analysis.

\section{Western blot experiment}

The measurement of protein concentration from the gastric homogenate was carried out according to Bradford's colorimetric method. ${ }^{25}$ Total protein from all groups $(200 \mathrm{mg} / \mathrm{mL})$ was dissolved with Laemmli buffer (PB buffer 0.5 M, pH 6.8; glycerol, SDS $10 \%$, bromophenol $0.1 \%$, mercaptoethanol) prior to separation onto $10 \%$ acrylamide gel. The transfer of protein bands from the gel onto a nitrocellulose membrane was done overnight. The specific primary antibodies, including $\beta$-actin $(1: 10,000)$, Bax $(1: 1,000)$ and Hsp70 $(1: 1,000)$ (Santa Cruz Biotechnology, Dallas, TX, USA), were added onto separate membranes and incubated for an hour. The primary antibodies were then conjugated with secondary antibodies and incubated for another hour. The bands were detected by the chemiluminescence lightdetecting kit (SuperSignal West Femto Chemiluminescent Substrate; Thermo Fisher Scientific, Waltham, MA, USA) and photographed.

\section{Statistical analysis}

All analyses were recorded as mean \pm standard error of the mean $(n=6)$. The statistical significance differences of the $P$-value between groups were assessed according to Tukey's honest significance difference and one-way analysis of variance (SPSS version 20). A value of $P<0.05$ was considered significant. All assays were performed in triplicate. The metadata of studied plant is provided in the Supplementary materials.

\section{Results}

\section{Evaluation of $A$. sesquipedalis constituents}

Preliminary phytochemical screening of $A$. sesquipedalis provides information about the constituents present in the 
Table I Phytochemical analysis of methanol leaf extract of Actinodaphne sesquipedalis

\begin{tabular}{lllll}
\hline \multicolumn{2}{l}{ Constituents } & & & \\
\hline Alkaloids & Saponins & $\begin{array}{l}\text { Sterols and } \\
\text { triterpenes }\end{array}$ & Polyphenols & Tannins \\
\hline $4+$ & $2+$ & - & $3+$ & $4+$ \\
\hline
\end{tabular}

Notes: "+" indicates the presence of compounds, while "-" indicates the absence.

extract. As shown in Table 1, the extract exhibited the presence of alkaloids, saponins, polyphenols and tannins. The constituents present in the highest level in the extracts are indicated by $4+$. Among them, alkaloids and tannins were more predominant in the extracts $(4+)$, while saponins were less predominant $(2+)$. The HPLC fingerprint of extract displayed an abundance of constituents as shown in the Supplementary materials.

\section{Evaluation of acute toxicity}

The evaluation of toxicity in rats treated with leaf extract of $A$. sesquipedalis at low $(1,000 \mathrm{mg} / \mathrm{kg})$ and high $(2,000 \mathrm{mg} / \mathrm{kg})$ doses exhibited no abnormal physiological, behavioral or body weight changes after 14 days of the treatment. Figure 1 shows the histological examination results of the liver and kidney which shows no toxicity was detected in both the organs. In addition, serum biochemical analysis (Tables 2 and 3) demonstrated no significant differences between groups treated with extracts and the control group, showing no toxic effects of leaf extract on animal models.

\section{Analysis of gastric acidity}

Analysis of the gastric acid substance (Table 4) showed a remarkable decrease of gastric acidity in pretreated groups (groups 3-5) compared with ulcer control group. The acidity substance in normal group (group 1) exhibited no significant differences $(P>0.05)$ when compared with the pretreated groups. The leaf extract at both doses produced lower acidity with higher $\mathrm{pH}$ than omeprazole (group 3) used in positive control group.

\section{Analysis of gastric wall mucus}

As shown in Table 4, gastric wall mucus in rats pretreated with $A$. sesquipedalis extract increased at low and high doses compared with group 2. However, there was a significant increase $(P<0.05)$ of gastric wall mucus at a high dose (300 mg/kg) when compared to ulcer group (group 2) with $3.01 \pm 0.45 \mathrm{mg}$ Alcian blue $/ \mathrm{g}$ tissue.

\section{Macroscopic assessment of gastric lesions}

The macroscopic evaluation of $\mathrm{MeOH}$ extract is shown in Figure 2. The hemorrhagic lesions can be seen at the glandular portions in ulcer group. Meanwhile, the reduction of lesions was observed in the stomachs of rats pretreated with all extracts as compared to ulcer group. As shown in Table 4, the percentage of ulcer inhibition increased significantly in rats pretreated with extracts in a dose-dependent manner. The leaf extract at a dose of $300 \mathrm{mg} / \mathrm{kg}$ exhibited an ulcer inhibition rate of $74 \%$, and $71 \%$ at low dose $(150 \mathrm{mg} / \mathrm{kg})$.
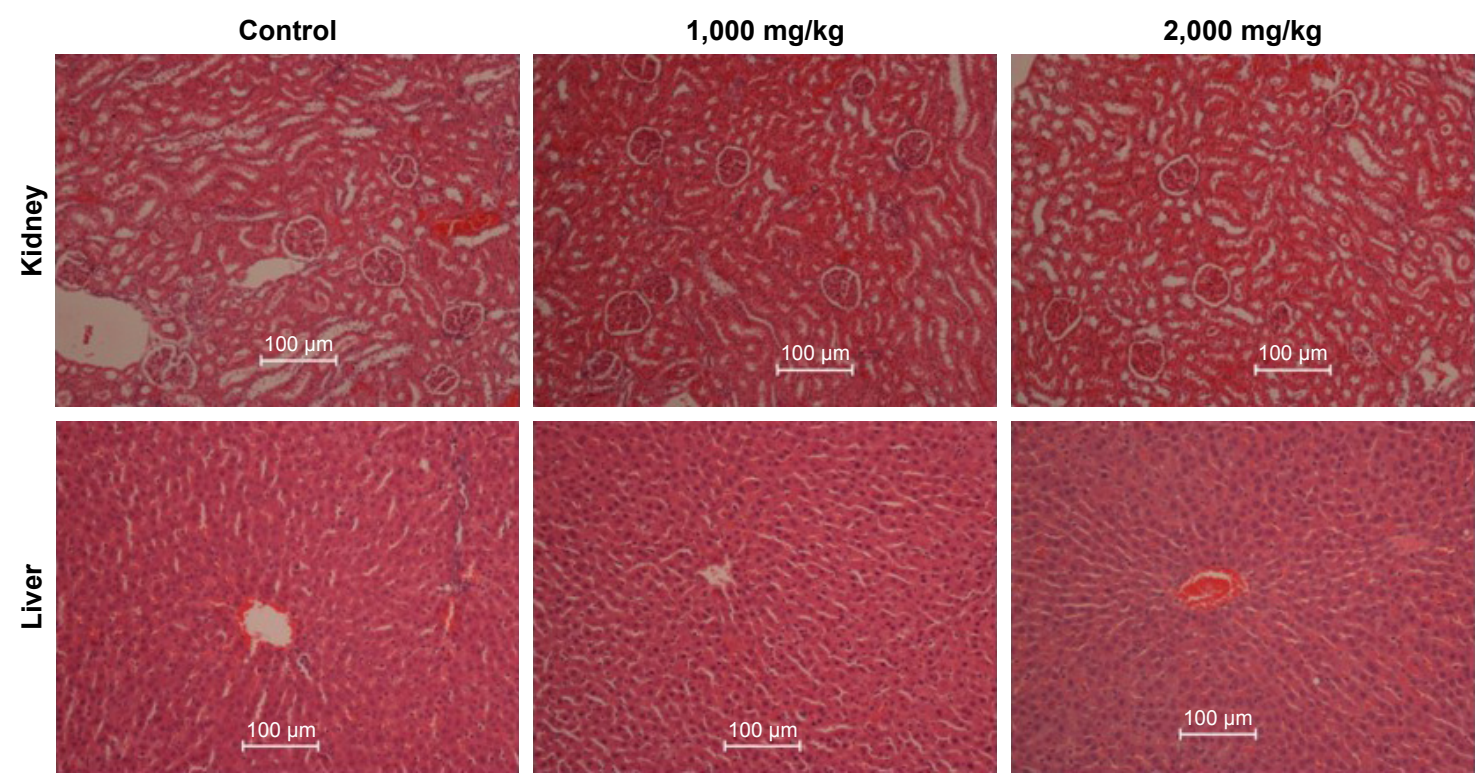

Figure I Histological analysis of the kidney and liver (hematoxylin and eosin staining, $\times 20$ ) for evaluating acute toxicity.

Notes: The mice were treated with low $(1,000 \mathrm{mg} / \mathrm{kg})$ and high doses $(2,000 \mathrm{mg} / \mathrm{kg})$ of leaf extract of Actinodaphne sesquipedalis. There are no significant differences between untreated (control) groups and groups treated with leaf extract. 
Table 2 Effects of Actinodaphne sesquipedalis extract on renal function in mice

\begin{tabular}{|c|c|c|c|c|c|c|c|}
\hline \multirow[t]{2}{*}{ Animal groups } & \multicolumn{7}{|c|}{ Renal function } \\
\hline & $\begin{array}{l}\text { Sodium } \\
\text { (mM/L) }\end{array}$ & $\begin{array}{l}\text { Pottasium } \\
(\mathrm{mM} / \mathrm{L})\end{array}$ & $\begin{array}{l}\text { Chloride } \\
\text { (mM/L) }\end{array}$ & $\begin{array}{l}\mathrm{CO}_{2} \\
(\mathrm{mM} / \mathrm{L})\end{array}$ & $\begin{array}{l}\text { Anion } \\
(\mathrm{mM} / \mathrm{L})\end{array}$ & $\begin{array}{l}\text { Urea } \\
(\mathrm{mM} / \mathrm{L})\end{array}$ & $\begin{array}{l}\text { Creatinine } \\
(\mu \mathrm{M} / L)\end{array}$ \\
\hline Control (Tween 20, 10\%, v/v) & $146.06 \pm 0.76$ & $4.7 I \pm 0.26$ & $105.22 \pm 1.29$ & $26.07 \pm 0.91$ & $18.13 \pm 0.96$ & $7.08 \pm 0.66$ & $35.24 \pm 1.87$ \\
\hline $2,000 \mathrm{mg} / \mathrm{kg}$ & $144.65 \pm 0.45$ & $4.42 \pm 0.65$ & $104.17 \pm 1.08$ & $27.7 I \pm 1.60$ & $15.92 \pm 1.58$ & $6.39 \pm 0.54$ & $37.33 \pm 1.38$ \\
\hline $\mathrm{I}, 000 \mathrm{mg} / \mathrm{kg}$ & $142.37 \pm 0.55$ & $4.53 \pm 0.11$ & $103.28 \pm 1.62$ & $28.33 \pm 1.07$ & $17.05 \pm 1.18$ & $7.15 \pm 0.82$ & $37.81 \pm 1.79$ \\
\hline
\end{tabular}

\section{Histological assessment of gastric lesions}

As shown in Figure 3, the H\&E staining showed severe mucosal damage and leukocyte infiltration into the mucosa of ulcer group. However, the destruction of gastric mucosa decreased in rats pretreated with omeprazole (group 3) and leaf extract (groups 4 and 5). Meanwhile, Periodic Acid Schiff (PAS) staining (Figure 4) exhibited an increase in intensity of magenta color in pretreated rats as compared to ulcer group, indicating an increase of glycoprotein uptake in the gastric mucosa. In addition, the intensity increased in a dose-dependent manner with 150 and $300 \mathrm{mg} / \mathrm{kg}$ of leaf extract.

\section{Immunohistochemical analysis}

The results of immunohistochemical analysis of Bax and Hsp70 are shown in Figures 5 and 6, respectively. The expression of Hsp70 protein in ulcer group was reduced when compared with groups 3-5. Upon pretreatment with omeprazole (group 3) and leaf extract (groups 4 and 5), the rats showed upregulation of Hsp70 protein with increase of brown color stain. In contrast, the Bax protein displayed downregulation of expression in rats pretreated with omeprazole and leaf extract by decrease of brown color stain compared with ulcer group.

\section{Analysis of biochemical substances of MDA and $\mathrm{PGE}_{2}$ and protein concentration}

The MDA, $\mathrm{PGE}_{2}$ and protein levels are shown in Table 5. The MDA levels of rats treated with the leaf extract of both doses
(150 and $300 \mathrm{mg} / \mathrm{kg}$ ) showed significant decrease $(P<0.05)$ when compared with the ulcer group (group 2) (Table 5). In contrast, the extracts also exhibited no significant differences $(P>0.05)$ when compared with omeprazole which was a control positive drug. Meanwhile, there was an enhancement of $\mathrm{PGE}_{2}$ levels in ulcer group (group 2) compared to rats which was given omeprazole (group 3 ) and A. sesquipedalis extract (groups 4 and 5) (Table 5). There was a significant increase $(P<0.05)$ of $\mathrm{PGE}_{2}$ level in pretreated rats (group $3-5$ ) when compared with group 2. Furthermore, the $\mathrm{PGE}_{2}$ levels of extract-pretreated rats were comparable with omeprazole group (group 3) with no significant differences $(P>0.05)$. Protein concentration in the gastric homogenate of rats pretreated with $A$. sesquipedalis extract showed a slight increase when compared with ulcer group (group 2) as shown in Table 5. There were also significant differences $(P<0.05)$ detected between groups 4 and 5 compared to omeprazole group (group 3).

\section{Antioxidant analysis of stomach homogenate}

Rats pretreated with omeprazole (group 3) and A. sesquipedalis extract (150 and $300 \mathrm{mg} / \mathrm{kg}$ ) (groups 4-5) had an increase in activities of antioxidants enzyme of NO, GSH and SOD (Figure 7). The levels of GSH, NO and SOD in the gastric homogenates of the pretreated groups (omeprazole and extract) were significantly increased $(P<0.05)$ compared to ulcer group (group 2). As shown in Figure 7, the GSH levels of groups pretreated with extract at a higher dose $(300 \mathrm{mg} / \mathrm{kg})$

Table 3 Effects of Actinodaphne sesquipedalis extract on liver function in mice

\begin{tabular}{|c|c|c|c|c|c|c|c|c|c|}
\hline \multirow{2}{*}{$\begin{array}{l}\text { Animal } \\
\text { groups }\end{array}$} & \multicolumn{9}{|c|}{ Liver function } \\
\hline & $\begin{array}{l}\text { Total } \\
\text { protein } \\
\text { (g/L) }\end{array}$ & $\begin{array}{l}\text { Albumin } \\
\text { (g/L) }\end{array}$ & $\begin{array}{l}\text { Globulin } \\
\text { (g/L) }\end{array}$ & $\begin{array}{l}\text { Total } \\
\text { bilirubin } \\
(\mu \mathrm{M} / \mathrm{L})\end{array}$ & $\begin{array}{l}\text { Conjugated } \\
\text { bilirubin } \\
(\mu \mathrm{M} / \mathrm{L})\end{array}$ & $\begin{array}{l}\text { Alkaline } \\
\text { phosphatase } \\
\text { (IU/L) }\end{array}$ & $\begin{array}{l}\text { Alanine } \\
\text { transaminase } \\
\text { (IU/L) }\end{array}$ & $\begin{array}{l}\text { Aspartate } \\
\text { transaminase } \\
(I U / L)\end{array}$ & $\begin{array}{l}\text { Gamma-glutamyl } \\
\text { transferase } \\
\text { (IU/L) }\end{array}$ \\
\hline $\begin{array}{l}\text { Control } \\
\text { (Tween 20, } \\
10 \%, v / v)\end{array}$ & $62.17 \pm 1.39$ & $39.05 \pm 2.04$ & $20.02 \pm 1.14$ & $2.00 \pm 0.00$ & $1.00 \pm 0.00$ & $143.36 \pm 3.04$ & $49.55 \pm 3.41$ & $169.08 \pm 2.98$ & $2.00 \pm 0.00$ \\
\hline $2,000 \mathrm{mg} / \mathrm{kg}$ & $59.52 \pm 1.07$ & $34.26 \pm 2.53$ & $18.18 \pm 1.92$ & $2.00 \pm 0.00$ & $1.00 \pm 0.00$ & $135.77 \pm 2.96$ & $48.38 \pm 2.75$ & $|62.84 \pm 3.7|$ & $2.00 \pm 0.00$ \\
\hline I,000 mg/kg & $60.37 \pm 125$ & $36.11 \pm 1.91$ & $16.95 \pm 1.64$ & $2.00 \pm 0.00$ & $1.00 \pm 0.00$ & $138.02 \pm 2.67$ & $47.91 \pm 3.25$ & $167.35 \pm 3.57$ & $2.00 \pm 0.00$ \\
\hline
\end{tabular}


Table 4 Effects of Actinodaphne sesquipedalis extracts on ulcer index, percentage inhibition, gastric mucus content and pH of gastric content

\begin{tabular}{|c|c|c|c|c|c|}
\hline $\begin{array}{l}\text { Animal } \\
\text { group }\end{array}$ & Pretreatment & $\begin{array}{l}\text { Ulcer index } \\
\left(\mathrm{mm}^{2}\right)\end{array}$ & $\begin{array}{l}\text { Inhibition } \\
\text { (\%) }\end{array}$ & $\begin{array}{l}\text { Mucus content (mg } \\
\text { Alcian blue/g tissue) }\end{array}$ & $\begin{array}{l}\text { pH of gastric } \\
\text { content }\end{array}$ \\
\hline I & Vehicle (normal control) & 0 & 0 & $1.99 \pm 0.07$ & $3.00 \pm 0.78$ \\
\hline 2 & Vehicle (ulcer control) & $496.5 \pm 6.89$ & 0 & $1.15 \pm 0.11$ & $1.67 \pm 0.99$ \\
\hline 3 & Omeprazole (20 mg/kg) & $115.0 \pm 6.87^{*}$ & $77.0^{*}$ & $4.69 \pm 0.10^{*}$ & $3.62 \pm 0.10^{*}$ \\
\hline 4 & Leaves extract (I 50 mg/kg) & $144.8 \pm 9.99 *, \#$ & $71.0^{*}$ & $1.82 \pm 0.06^{\#}$ & $4.04 \pm 0.08 *$ \\
\hline 5 & Leaves extract (300 mg/kg) & $130.7 \pm 4.92^{*, \#}$ & $74.0 *$ & $3.01 \pm 0.45 *$ & $4.20 \pm 0.02 *$ \\
\hline
\end{tabular}

Notes: Data are reported as mean \pm standard error of the mean $(n=6)$. $* P<0.05$ compared to group 2 ; ${ }^{\#}<0.05$ compared to group 3 . All the biological assays were done in triplicate.

were higher with no significant differences $(P>0.05)$ compared with omeprazole control positive drug group. Meanwhile, the SOD level of group 5 was $25.4 \pm 0.04 \mathrm{U} / \mathrm{mg}$ protein compared to group 4 with $19.5 \pm 0.08 \mathrm{U} / \mathrm{mg}$ protein. The NO level of rats pretreated with extract was comparable with omeprazole group ( $8.4 \pm 0.09 \mathrm{~mol} / \mathrm{g}$ tissue) with no significant differences ( $P>0.05)$ compared to group $4(7.2 \pm 0.02 \mathrm{~mol} / \mathrm{g}$ tissue $)$ and group $5(7.9 \pm 0.01 \mathrm{~mol} / \mathrm{g}$ tissue $)$.

\section{Western blot analysis}

The protein expression analysis of Bax and Hsp70 is shown in Figure 8. Results showed that Hsp70 expression was significantly increased, while a decrease in Bax expression
$(P<0.05)$ was observed when compared with ulcer group (group 2). The group treated with extract at $300 \mathrm{mg} / \mathrm{kg}$ exhibited the highest expression of Hsp70 protein with 1.10-fold changes. Meanwhile, the group treated with same dose $(300 \mathrm{mg} / \mathrm{kg}$ ) of extract showed lower expression of Bax protein compared to the group treated with $150 \mathrm{mg} / \mathrm{kg}$ with 0.83 -fold changes.

\section{Discussion}

The present study exhibits the capability of leaf extract of A. sesquipedalis of preventing ethanol-induced gastric ulcer in rats' stomach. Ethanol has been widely used by researchers to induce gastric acute hemorrhagic lesion in animal
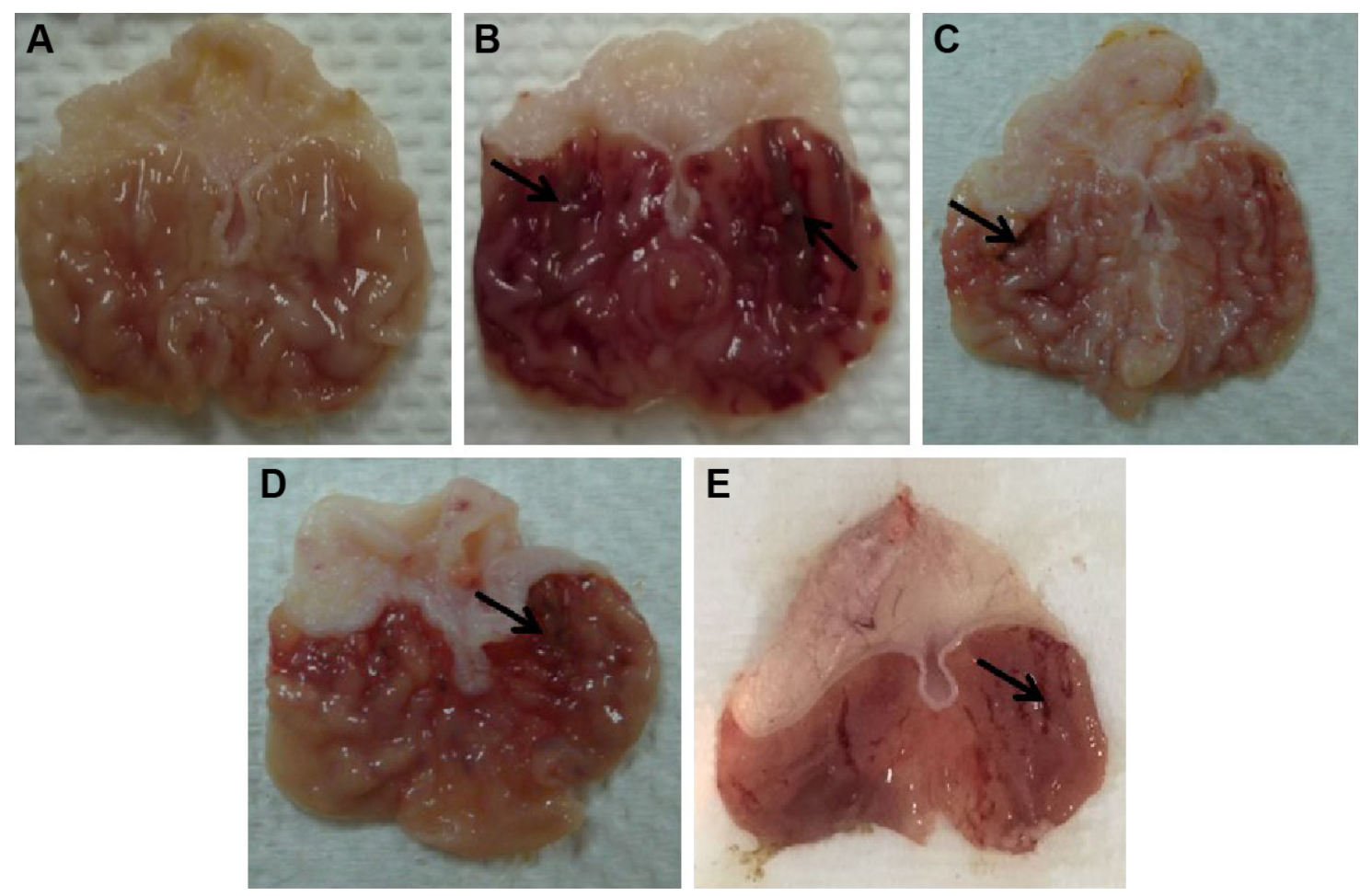

Figure 2 Macroscopic appearance of the gastric mucosa induced by ethanol in the normal and pretreated rat groups ( $n=6)$.

Notes: (A) Normal control (10\% Tween 20). (B) Ulcer control (absolute EtOH) shows remarkably severe hemorrhagic lesions as indicated by black arrow. (C) Stomach pretreated with omeprazole (20 mg/kg) exhibits less lesions. (D and E) Stomachs pretreated with low (150 mg/kg) and high dose (300 mg/kg) of leaf extract, respectively, show reduction in the gastric lesions. 

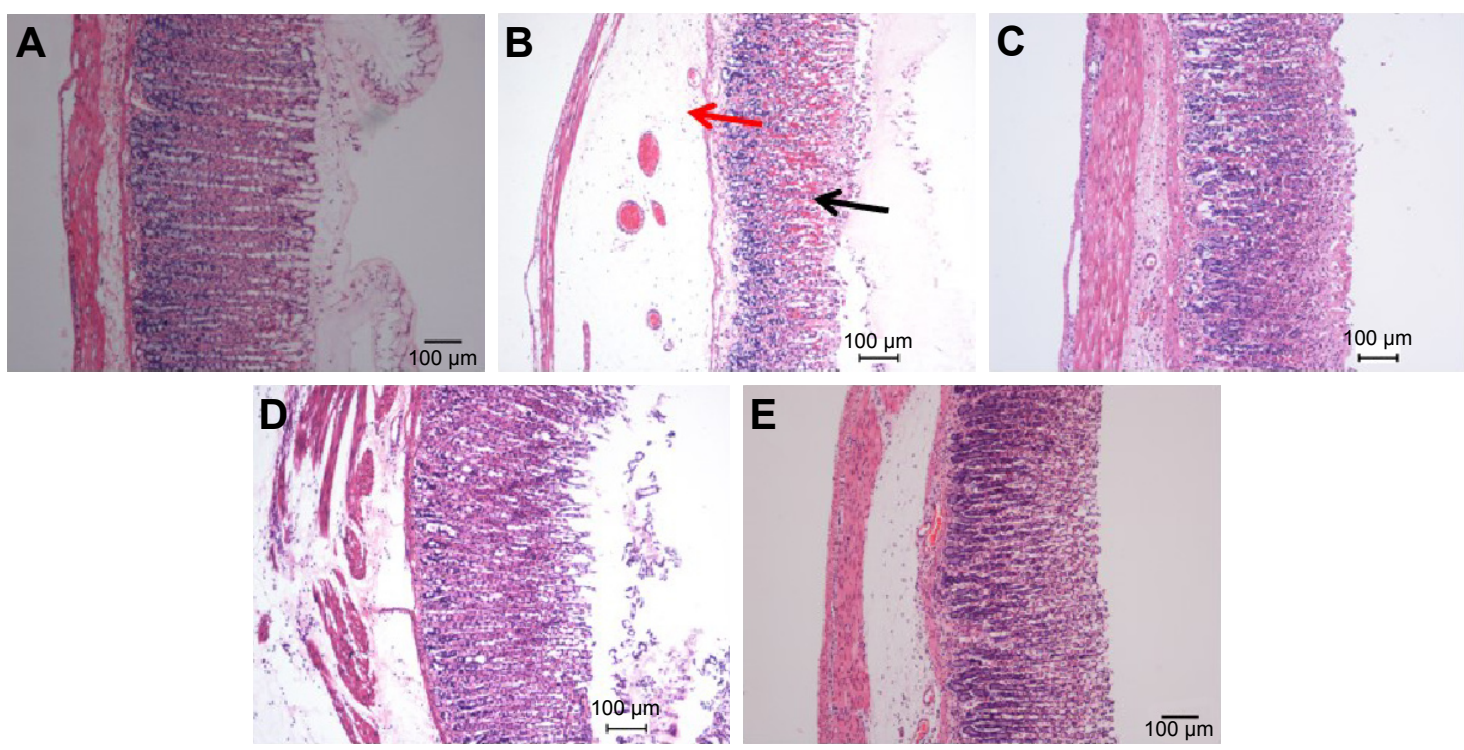

Figure 3 H\&E staining of the gastric epithelium of each group of rats.

Notes: (A) Normal group without ethanol induction (10\% Tween 20). (B) Ulcer group (absolute EtOH) with severe mucosal damages (black arrow) and leukocyte penetration (red arrow) along submucosal layer. (C-E) Stomachs pretreated with omeprazole (20 mg/kg) and leaf extract of low (I50 mg/kg) and high (300 mg/kg) doses, respectively, show decreased mucosal damage.

Abbreviation: H\&E, hematoxylin and eosin.

models; $;^{11,17,26}$ as a consequence, gastric ulcer will be formed due to vascular damage and gastric cell necrosis..$^{27}$ The doses of 150 and $300 \mathrm{mg} / \mathrm{kg}$ of $A$. sesquipedalis leaf extract resulted in a reduction of gastric ulcer and therefore exhibited potential gastroprotective effects in rats' stomach. In addition, the extract also showed no acute toxicity in animal models even at high doses, as illustrated in Figure 1 and Tables 2 and 3. These results indicated that oral consumption of $A$. sesquipedalis extract for the treatment of gastric ulcer does not cause toxicity in both the liver and renal system.

The effectiveness of A. sesquipedalis leaf extract as a gastroprotective agent has been proven through various
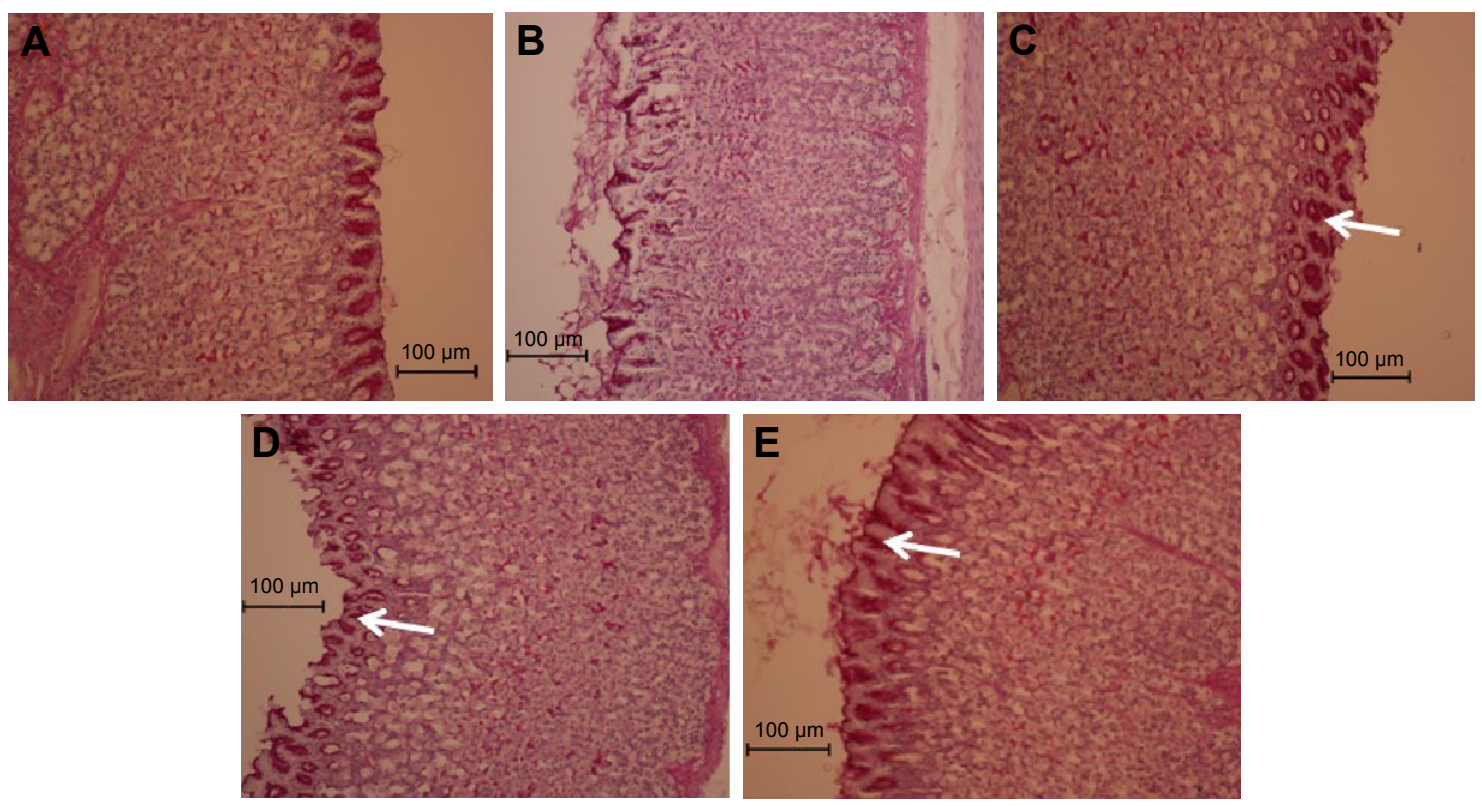

Figure 4 Histological appearance of stomachs mucosa after PAS staining.

Notes: (A) Normal control group (I0\% Tween 20). (B) Ulcer group (absolute EtOH) shows severe destruction of gastric mucosa and mucus glands. (C) Stomach pretreated with omeprazole $(20 \mathrm{mg} / \mathrm{kg}$ ) exhibits increased intensity of magenta color, corresponding to glycoprotein secretion (white arrow). (D and E) Stomachs pretreated with leaf extract of low $(150 \mathrm{mg} / \mathrm{kg})$ and high $(300 \mathrm{mg} / \mathrm{kg})$ doses, respectively, showing dose-dependently increased intensities of PAS staining. Abbreviation: PAS, periodic Acid Schiff. 

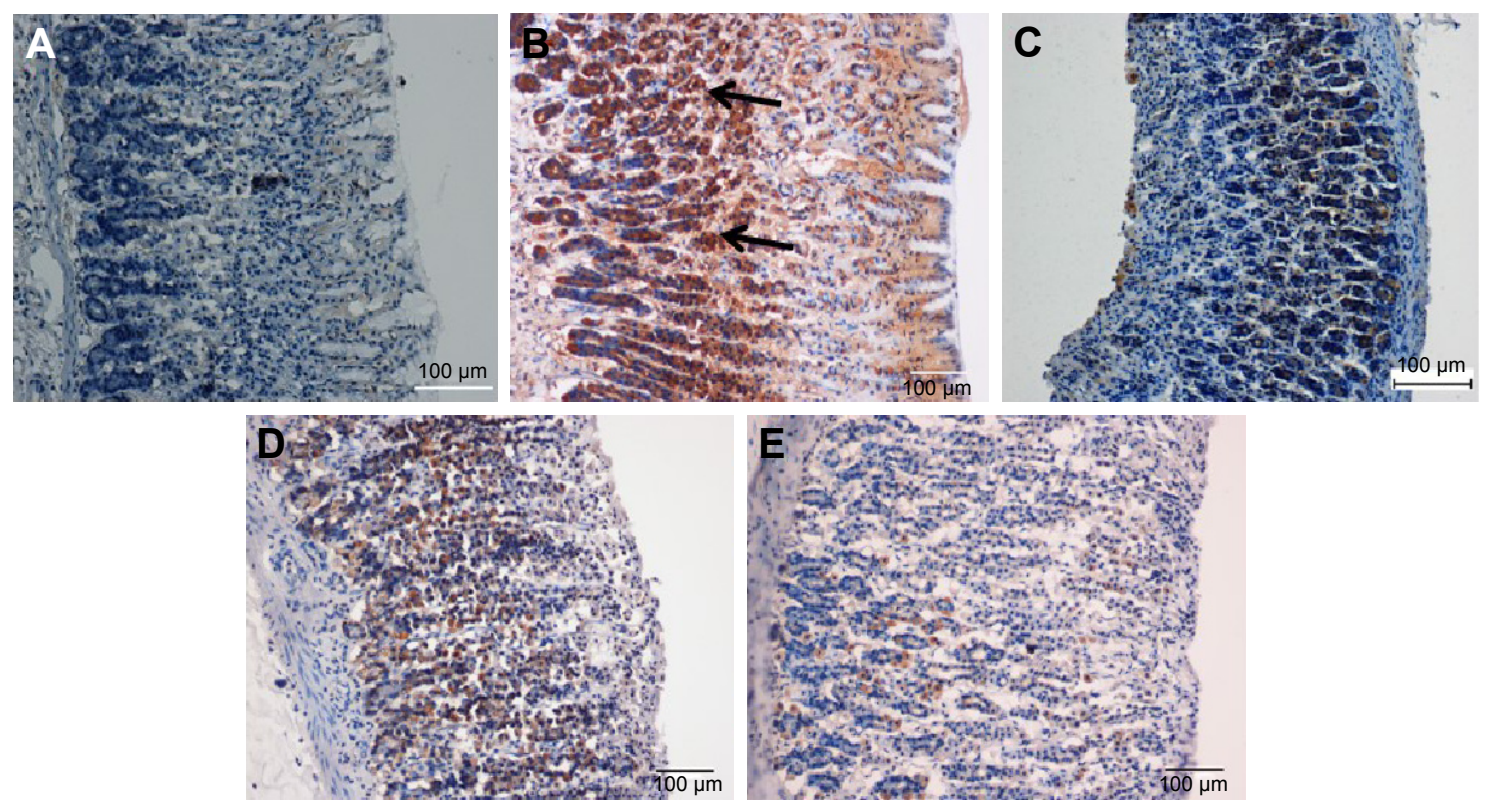

Figure 5 Effects on Bax protein expression determined through immunohistochemical analysis.

Notes: (A) Normal control group (10\% Tween 20). (B) Ulcer group (absolute EtOH) shows high expression of Bax protein as shown by brown color stain (black arrow). (C) Stomachs pretreated with omeprazole $(20 \mathrm{mg} / \mathrm{kg})$ exhibit less expression of Bax protein. (D and E) Stomachs pretreated with leaf extract of low (I50 mg/kg) and high $(300 \mathrm{mg} / \mathrm{kg})$ doses, respectively, display less expression of Bax protein with reduction of brown stain.

experimental studies. Previously, the genus Actinodaphne was also used as a traditional Chinese medicine for the treatment of stomachache..$^{28}$ Actinodaphne plants are rich in diverse biological active alkaloids, which have phytopharmaceutical properties, such as dicentrine, liriodenine, (+)-N-(2-hydroxypropyl) lindcarpine, boldine, norboldine, lindcarpine and methyllindcarpine. ${ }^{29-32}$ As shown in Table 1 , alkaloids contribute the most secondary constituents in the studied plant that could potentially act as inhibitors to prevent gastric ulcer.

The effects of A. sesquipedalis leaf extract in rat stomachs were compared with omeprazole which was used as a control

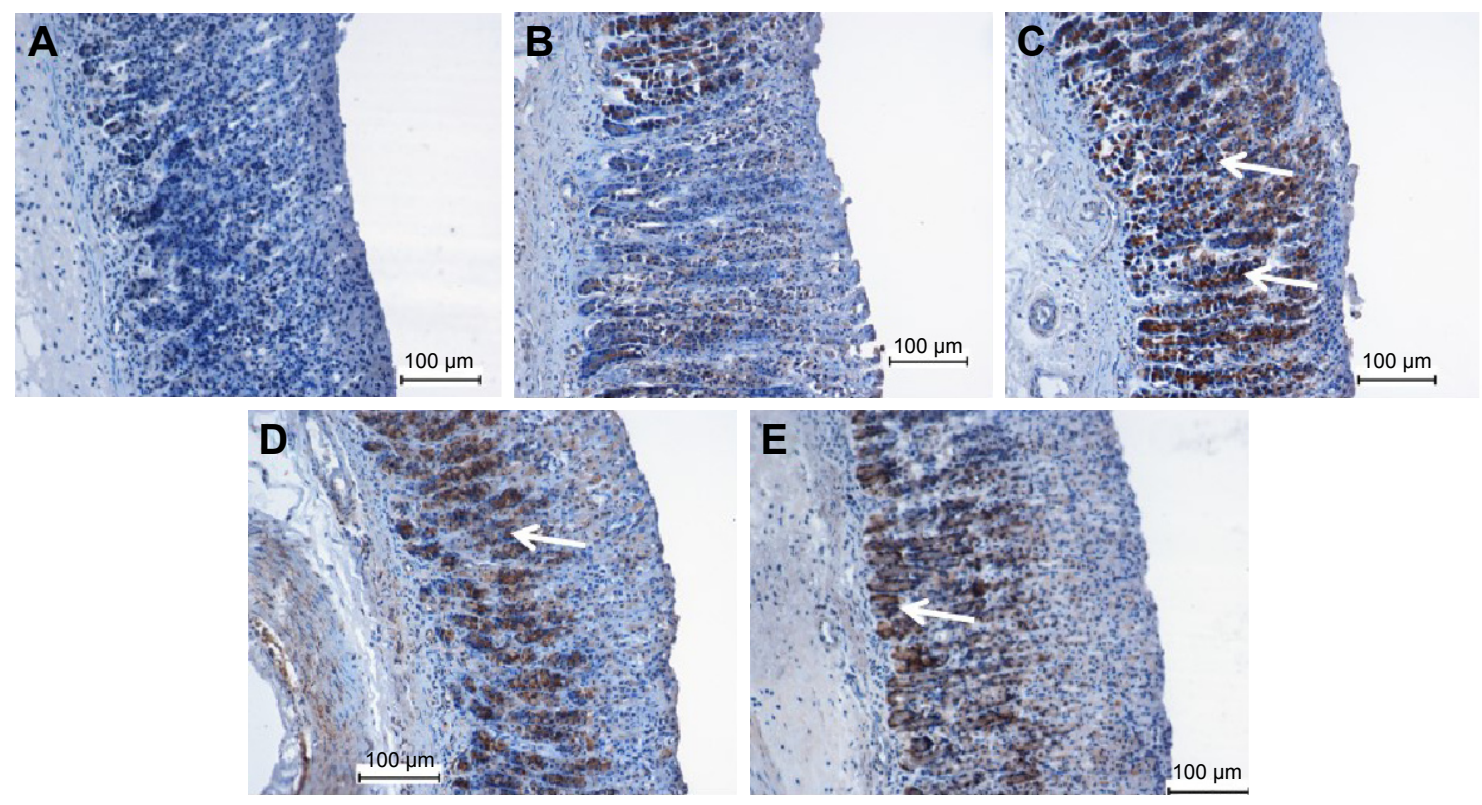

Figure 6 Effects on Hsp70 protein expression determined through immunohistochemical analysis.

Notes: (A) Normal control group (10\% Tween 20). (B) Ulcer group (absolute EtOH) shows less expression of Hsp70 protein. (C) Rats pretreated with omeprazole $(20 \mathrm{mg} / \mathrm{kg}$ ) show high expression of Hsp70 protein as indicated by brown color stain (white arrow). (D and E) Rats pretreated with the leaf extract of low (I50 mg/kg) and high $(300 \mathrm{mg} / \mathrm{kg})$ doses, respectively, show high expression of Hsp70 protein. 
Table 5 Effects of Actinodaphne sesquipedalis extracts on the levels of MDA, $\mathrm{PGE}_{2}$ and protein

\begin{tabular}{lllll}
\hline Animal group & Pretreatment & MDA $(\mu \mathbf{m o l} / \mathbf{g}$ tissue $)$ & PGE $_{\mathbf{2}}(\mathbf{n g} / \mathbf{m g})$ & Protein $(\mathbf{m g} / \mathbf{m L})$ \\
\hline 1 & Vehicle (normal control) & $17.4 \pm 0.42$ & $3.5 \pm 0.13$ & $19.1 \pm 0.51$ \\
2 & Vehicle (ulcer control) & $43.6 \pm 0.82$ & $2.1 \pm 0.07$ & $11.4 \pm 0.40$ \\
3 & Omeprazole $(20 \mathrm{mg} / \mathrm{kg})$ & $23.3 \pm 0.50^{*}$ & $3.2 \pm 0.07^{*}$ & $16.1 \pm 0.53^{*}$ \\
4 & Leaves extract $(150 \mathrm{mg} / \mathrm{kg})$ & $29.9 \pm 2.73^{*}$ & $2.8 \pm 0.04^{*}$ & $12.1 \pm 0.35^{\#}$ \\
5 & Leaves extract $(300 \mathrm{mg} / \mathrm{kg})$ & $29.6 \pm 2.59^{*}$ & $3.5 \pm 0.04^{*}$ & $12.6 \pm 0.3 \mathrm{I}^{\#}$ \\
\hline
\end{tabular}

Notes: All values are reported as mean \pm standard error of the mean. $P<0.05$ was considered significant when compared with the group $2(*)$ and group $3(*)$. For each group, $\mathrm{n}=6$.

Abbreviations: MDA, malondialdehyde; $\mathrm{PGE}_{2}$, prostaglandin $\mathrm{E}_{2}$.

positive drug. The leaf extract showed comparable action with omeprazole by preventing acid secretion in the stomach. ${ }^{21}$ Administration of ethanol can lead to production of a high amount of acid content which leads to gastric ulcer. ${ }^{33}$ Pretreatment with A. sesquipedalis leaf extract reduced the acidity in rat stomach and subsequently increased the $\mathrm{pH}$ of the gastric substance as shown in Table 4 . Another factor that protects the stomach from ulcer injury is the gastric mucus. The presence of gastric mucus enhances the protection of gastric wall from gastric acid, as well as acting as a barrier against self-digestion. ${ }^{34}$ Gastric ulcer can be treated by the administration of leaf extract of $A$. sesquipedalis for the significant production of gastric mucus (Table 4). Results from the PAS study also supported the evidence of mucus production in pretreated rats with increasing intensity of magenta color, as illustrated in Figure 4. A comparable study conducted by Nordin et al on Enicosanthellum pulchrum extracts exhibited an increase in gastric $\mathrm{pH}$ and mucus in pretreated rats, suggesting the capability of plant extracts in defending the gastric tissue from ethanol damage. ${ }^{23}$

More promising evidence has been shown for the prevention of gastric ulcers through microscopic assessment.
As shown in Figure 3, infiltration of leukocytes into ulcerated gastric endothelia decreased in groups 4 and 5 consisting of rats pretreated with the extract, suggesting protection from ulcers in rats' stomachs. High accumulation and infiltration of leukocytes may cause tissue damage in gastric mucosa and also failure of microcirculation. ${ }^{35}$ Therefore, these adverse effects were restored by pretreating the rats' stomachs with leaf extract of $A$. sesquipedalis.

$\mathrm{PGE}_{2}$ acts as a mediator in the gastrointestinal mucosal system to regulate the mucus secretion from gastric mucosa exhibiting defensive effects in gastric injury models. ${ }^{18}$ Gastric mucus was highly produced in the rats pretreated with extract, and an increase in $\mathrm{PGE}_{2}$ level in both groups 4 and 5 (Table 5) was observed proving the vital function of $\mathrm{PGE}_{2}$ in regulating the mucus production. $\mathrm{PGE}_{2}$ also plays a crucial role by maintaining the cellular integrity of the gastric mucosa. ${ }^{36}$ Therefore, leaf extract decreased the gastric injury with a significant increase of $\mathrm{PGE}_{2}$ content in the gastric mucosa in comparison to omeprazole (group 3). On the contrary, MDA displayed a reverse action in gastric ulcer when rats were pretreated with leaf extract of A. sesquipedalis. In general, MDA is a product of lipid peroxidation that

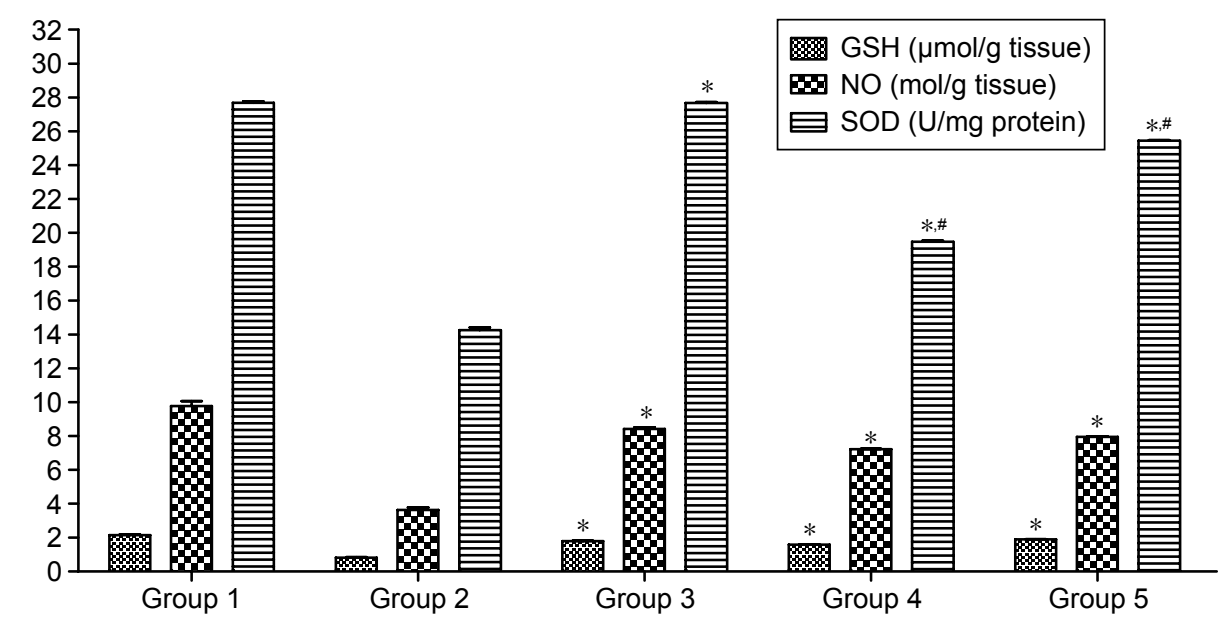

Figure 7 Effects of the extracts on GSH, NO and SOD levels.

Notes: Groups I-3 correspond to negative control of Tween 20, ethanol $95 \%$ and control positive (omeprazole, $20 \mathrm{mg} / \mathrm{mL}$ ), respectively. The experimental groups (4 and 5 ) received 150 and $300 \mathrm{mg} / \mathrm{kg}$ of leaf extract, respectively. All values are reported as mean \pm standard error of mean with $P<0.05$ considered significant. Significant difference when compared with group $2(*)$ and group $3(*)$.

Abbreviations: GSH, glutathione; NO, nitric oxide; SOD, superoxide dismutase. 


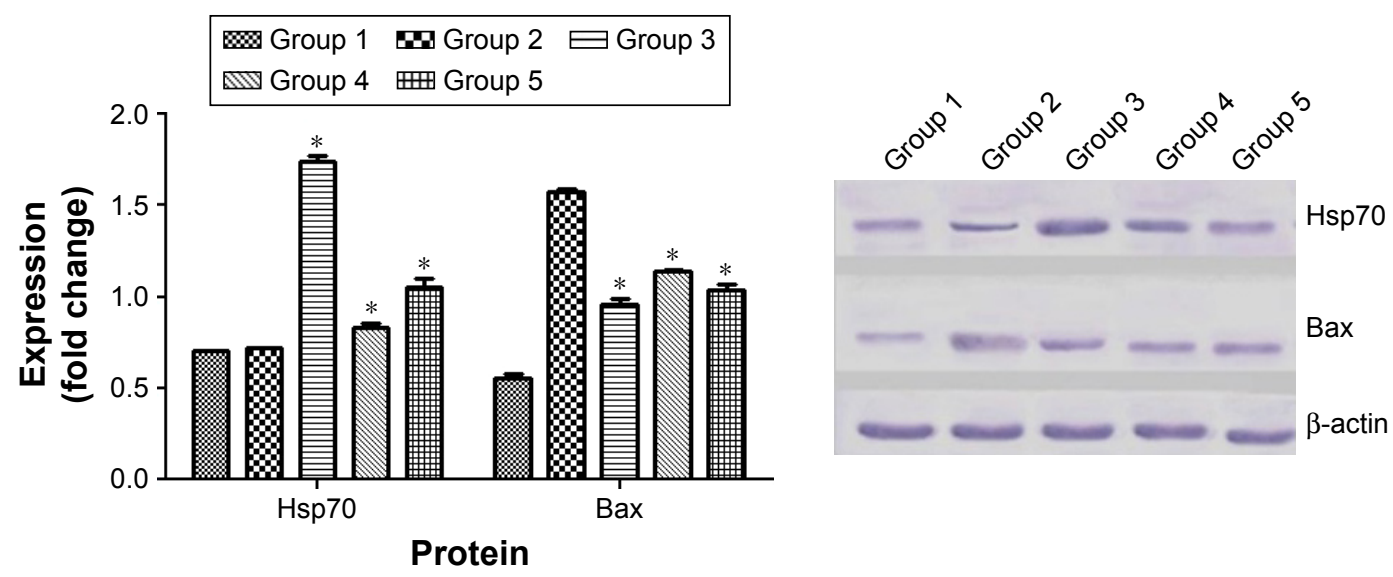

Figure 8 Effects of leaf extract of Actinodaphne sesquipedalis on the Hsp70 and Bax expression determined using $\beta$-actin as a housekeeping protein. Notes: Groups I and 2 represent negative control of Tween 20 and ethanol 95\%, respectively. Group 3 represents control positive drug (omeprazole). The experimental groups (4 and 5) received 150 and $300 \mathrm{mg} / \mathrm{kg}$ extract, respectively. *Statistical significance of all data is expressed as $P<0.05$.

causes cell membrane damage ${ }^{37}$ and is also considered as a marker of gastric ulcer due to reactive oxygen species (ROS) formation. ${ }^{38}$ The reduction of MDA observed in the present study demonstrated that $A$. sesquipedalis leaf extract is able to inhibit lipid peroxidation produced by ethanol.

Experiments have also been conducted on antioxidants such as GSH and NO and antioxidant enzymes such as SOD for determination of antioxidant mediators of oxidative stress. The presence of antioxidant enzymes in gastric ulcer minimizes the tissue injury in human diseases. ${ }^{39}$ The production of GSH and $\mathrm{NO}$ is essential in maintaining the ROS and preventing tissue injury and oxidative stress. ${ }^{16}$ In addition, ROS are also associated with formation of hydrogen peroxide which in turn is converted into a stable form by SOD acting as an antioxidant mediator. ${ }^{40}$ Tissue injury caused by ROS was reduced when leaf extract of A. sesquipedalis was administered in rats' stomachs, resulting in elevation of GSH, NO and SOD levels as shown in Figure 7. Increasing level of $\mathrm{NO}$, which is also involved in secretion of mucus ${ }^{39}$ proved higher production of mucus as shown in Table 4. The mechanism of action that causes SOD to increase in pretreated rats was possibly a result of lipid peroxide reduction through ROS production. ${ }^{41}$ Therefore, an increased amount of antioxidant and antioxidant enzyme was observed in the stomachs of rats in groups 4-9, suggesting the antioxidant activities of the leaf extract in reducing gastric ulcers.

The action of $A$. sesquipedalis leaf extract on the gastric ulcers was also studied using two apoptotic proteins, Hsp70 and Bax. Hsp70 plays a vital role in protecting cells from oxidative stress or heat shock. ${ }^{42}$ Bax is a proapoptotic protein belonging to Bcl-2 family which induces apoptosis via mitochondrial pathway. ${ }^{43}$ As shown in Figure 8, upregulation of Hsp70 protein in experimental groups 4-9 demonstrated that the gastric cells were protected by $A$. sesquipedalis leaf extract from ulcer injury induced by ethanol. In contrast, the downregulation of Bax protein in rats pretreated with the extracts lad to the prevention of apoptosis in the gastric cells. ${ }^{44,45}$ Results from immunohistochemical analysis and Western blotting experiments suggest that elevation of Hsp70 expression and depletion of Bax expression upon administration of leaf extracts protect gastric cells from ethanol injury.

Promising results from this study on the use of A. sesquipedalis leaf extract against gastric ulcer proved its potential to be developed as an agent to protect gastric tissue from superficial mucosal lesions caused by ethanol.

\section{Acknowledgments}

The authors acknowledge the University of Malaya which provided financial support through PPP grant (PV091/2011B) and UMRG grant (RP043B-15HTM) to conduct this study. They also thank late Prof Datuk, Dr A Hamid A Hadi, Prof Dr Berna Elya, Dr Shahram Golbabapour and Ms Farah Humaira Mohamad Nasir for their help throughout this study.

\section{Disclosure}

The authors report no conflicts of interest in this work.

\section{References}

1. Brown LF, Wilson DE. Gastroduodenal ulcers: causes, diagnosis, prevention and treatment. Compr Ther. 1999;25(1):30-38.

2. Jain KS, Shah AK, Bariwal J, et al. Recent advances in proton pump inhibitors and management of acid-peptic disorders. Bioorg Med Chem. 2007;15(3):1181-1205.

3. McColl KE. Clinical practice. Helicobacter pylori infection. $N$ Engl J Med. 2010;362(17):1597-1604.

4. Cowan WK. Genetics of duodenal and gastric ulcer. Clin Gastroenterol. 1973;2(3):539-546. 
5. Abdelwahab SI, Taha MM, Abdulla MA, et al. Gastroprotective mechanism of Bauhinia thonningii Schum. J Ethnopharmacol. 2013; 148(1):277-286

6. Golbabapour S, Hajrezaie M, Hassandarvish P, et al. Acute toxicity and gastroprotective role of $M$. pruriens in ethanol-induced gastric mucosal injuries in rats. Biomed Res Int. 2013;2013:974185.

7. Bandyopadhyay D, Biswas K, Bhattacharyya M, Reiter RJ, Banerjee RK. Involvement of reactive oxygen species in gastric ulceration: protection by melatonin. Indian J Exp Biol. 2002;40(6):693-705.

8. Mota KS, Dias GE, Pinto ME, et al. Flavonoids with gastroprotective activity. Molecules. 2009;14(3):979-1012.

9. Rouhollahi E, Moghadamtousi SZ, Hamdi OA, et al. Evaluation of acute toxicity and gastroprotective activity of Curcuma purpurascens BI. rhizome against ethanol-induced gastric mucosal injury in rats. $B M C$ Complement Altern Med. 2014;14:378.

10. Abdulla MA, Ahmed KA, Abu-Luhoom FM, Muhanid M. Role of Ficus deltoidea extract in the enhancement of wound healing in experimental rats. Biomed Res. 2010;21(3):241-245.

11. Hussaini J, Othman NA, Abdulla MA, Majid NA, Faroq HM, Ismail S. Gastroprotective effects of Dicranopteris linearis leaf extract against ethanol-induced gastric mucosal injury in rats. Sci Res Essays. 2012; 7(18):1761-1767.

12. Harborne J. Phytochemical Methods: A Guide to Modern Techniques of Plant Analysis. 3rd ed. Berlin: Springer Science \& Business Media; 1998.

13. Jacknoon AA, Elhefian EA, Mohammed AM, Hamdi OA, Yahaya AH. A preliminary qualitative study of two common Acacia species in Sudan. J Chem. 2012;9(2):851-856.

14. Odebiyi OO, Sofowora EA. Phytochemical screening of Nigerian medicinal plants II. Lloydia. 1978;41(3):234-246.

15. Mahmood AA, Mariod AA, Al-Bayaty F, Abdel-Wahab SI. Anti-ulcerogenic activity of Gynura procumbens leaf extract against experimentally-induced gastric lesions in rats. J Med Plants Res. 2010; 4(8):685-691.

16. Al Batran R, Al-Bayaty F, Jamil Al-Obaidi MM, et al. In vivo antioxidant and antiulcer activity of Parkia speciosa ethanolic leaf extract against ethanol-induced gastric ulcer in rats. PLoS One. 2013;8(5):e64751.

17. Ibrahim IA, Qader SW, Abdulla MA, Nimir AR, Abdelwahab SI, Al-Bayaty FH. Effects of Pithecellobium jiring $a$ ethanol extract against ethanol-induced gastric mucosal injuries in Sprague-Dawley rats. Molecules. 2012;17(3):2796-2811.

18. Abdulla MA, Ali HM, Ahmed KA, Noor SM, Ismail S. Evaluation of the anti-ulcer activities of Morus alba extracts in experimentally-induced gastric ulcer in rats. Biomed Res Int. 2009;20(1):35-39.

19. Mahmood AA, Al-Bayaty FH, Salmah I, Nor Syuhada AB, Harita H, Mughrabi FF. Enhancement of gastric ulcer by Areca catechu nut in ethanol-induced gastric mucosal injuries in rats. J Med Plants Res. 2011; 5(12):2562-2569.

20. McManus JF. Histological and histochemical uses of periodic acid. Stain Technol. 1948;23(3):99-108.

21. Hajrezaie M, Golbabapour S, Hassandarvish P, et al. Acute toxicity and gastroprotection studies of a new schiff base derived copper (II) complex against ethanol-induced acute gastric lesions in rats. PLoS One. 2012; 7(12): 51537.

22. Hajrezaie M, Salehen N, Karimian H, et al. Biochanin A gastroprotective effects in ethanol-induced gastric mucosal ulceration in rats. PLoS One. 2015;10(3): 0121529.

23. Nordin N, Salama SM, Golbabapour S, et al. Anti-ulcerogenic effect of methanolic extracts from Enicosanthellum pulchrum (King) Heusden against ethanol-induced acute gastric lesion in animal models. PLoS One. 2014;9(11):e111925.

24. Gornall AG, Bardawill CJ, David MM. Determination of serum proteins by means of the biuret reaction. J Biol Chem. 1949;177(2):751-766.

25. Cornish-Bowden A. Fundamentals of Enzyme Kinetics. 3rd ed. London: Portland Press; 2012.
26. Alrashdi AS, Salama SM, Alkiyumi SS, et al. Mechanisms of gastroprotective effects of ethanolic leaf extract of Jasminum sambac against HCl/ ethanol-induced gastric mucosal injury in rats. Evid Based Complement Alternat Med. 2012;2012:786426.

27. Mahmood A, Sidik K, Salmah I, Suzainor K, Philip K. Antiulcerogenic activity of Ageratum conyzoides leaf extract against ethanol-induced gastric ulcer in rats as animal model. Int J Mol Med Adv Sci. 2005;1(4): 402-405.

28. Kim CM, Shin MK, Ahn DK, Lee KS. Chinese medicine dictionary. Jungdam Co. 1998;6:3398.

29. Moghadamtousi SZ, Rouhollahi E, Karimian H, Fadaeinasab M, Abdulla MA, Kadir HA. Gastroprotective activity of Annona muricata leaves against ethanol-induced gastric injury in rats via Hsp70/Bax involvement. Drug Des Devel Ther. 2014;8:2099-2110.

30. Wiseman N, Ye F. A Practical Dictionary of Chinese Medicine. 2nd ed. Brookline, MA: Paradigm Publications; 1998.

31. Bhakuni DS, Gupta NC, Satish S, Sharma SC, Shukla YN, Tandon JS. Chemical constituents of Actinodaphne augustifolia, Croton sparsiflorus, Duabanga sonneratiodes, Glycosmis mauritiana, Hedyotis auricularia, Lyonia ovalifolia, Micromelum pubescens, Pyrus pashia and Rhododendron niveum. Phytochemistry. 1971;10(9):2247-2249.

32. Lu ST, Wang SJ, Lin FS. [Studies on the alkaloids of Formosan lauraceous plants. XIV. Alkaloids of Actinodaphne acutivena (hayata) Nakai and Litsea hayatae Kanehira]. Yakugaku Zasshi. 1969;89(9):1313-1316. Japanese [with English abstract].

33. Waldum HL, Arnestad JS, Brenna E, Eide I, Syversen U, Sandvik AK. Marked increase in gastric acid secretory capacity after omeprazole treatment. Gut. 1996;39(5):649-653.

34. Cone RA. Barrier properties of mucus. Adv Drug Deliv Rev. 2009;61(2): $75-85$.

35. Cheng CL, Koo MW. Effects of Centella asiatica on ethanol induced gastric mucosal lesions in rats. Life Sci. 2000;67(21):2647-2653.

36. Hamaguchi M, Kojima T, Ohbora A, Kato T, Takeda N, Fukui M. Identification of individuals with non-alcoholic fatty liver disease by the diagnostic criteria for the metabolic syndrome. World J Gastroenterol. 2012;18(13):1508-1516.

37. Royer M, Diouf PN, Stevanovic T. Polyphenol contents and radical scavenging capacities of red maple (Acer rubrum L.) extracts. Food Chem Toxicol. 2011;49(9):2180-2188.

38. Kwiecień S, Brzozowski T, Konturek SJ. Effects of reactive oxygen species action on gastric mucosa in various models of mucosal injury. J Physiol Pharmacol. 2002;53(1):39-50.

39. Ismail IF, Golbabapour S, Hassandarvish P, et al. Gastroprotective activity of Polygonum chinense aqueous leaf extract on ethanol-induced hemorrhagic mucosal lesions in rats. Evid Based Complement Alternat Med. 2012;2012:404012

40. Brzozowski T, Drozdowicz D, Konturek SJ, et al. Grapefruit-seed extract attenuates ethanol- and stress-induced gastric lesions via activation of prostaglandin, nitric oxide and sensory nerve pathways. World J Gastroenterol. 2005;11(41):6450-6458.

41. Blandizzi C, Fornai M, Colucci R, et al. Lansoprazole prevents experimental gastric injury induced by non-steroidal anti-inflammatory drugs through a reduction of mucosal oxidative damage. World J Gastroenterol. 2005;11(26):4052-4060.

42. Atalay M, Oksala N, Lappalainen J, Laaksonen DE, Sen CK, Roy S. Heat shock proteins in diabetes and wound healing. Curr Protein Pept Sci. 2009;10(1):85-95.

43. Adams JM, Cory S. The Bcl-2 apoptotic switch in cancer development and therapy. Oncogene. 2007;26(9):1324-1337.

44. Mayer M, Bukau B. Hsp70 chaperones: cellular functions and molecular mechanism. Cell Mol Life Sci. 2005;62(6):670-684.

45. Sreedhar AS, Csermely P. Heat shock proteins in the regulation of apoptosis: new strategies in tumor therapy: a comprehensive review. Pharmacol Ther. 2004;101(3):227-257. 


\section{Publish your work in this journal}

Drug Design, Development and Therapy is an international, peerreviewed open-access journal that spans the spectrum of drug design and development through to clinical applications. Clinical outcomes, patient safety, and programs for the development and effective, safe, and sustained use of medicines are the features of the journal, which has also been accepted for indexing on PubMed Central. The manuscript management system is completely online and includes a very quick and fair peer-review system, which is all easy to use. Visit http://www.dovepress.com/testimonials.php to read real quotes from published authors.

Submit your manuscript here: http://www.dovepress.com/drug-design-development-and-therapy-journal 